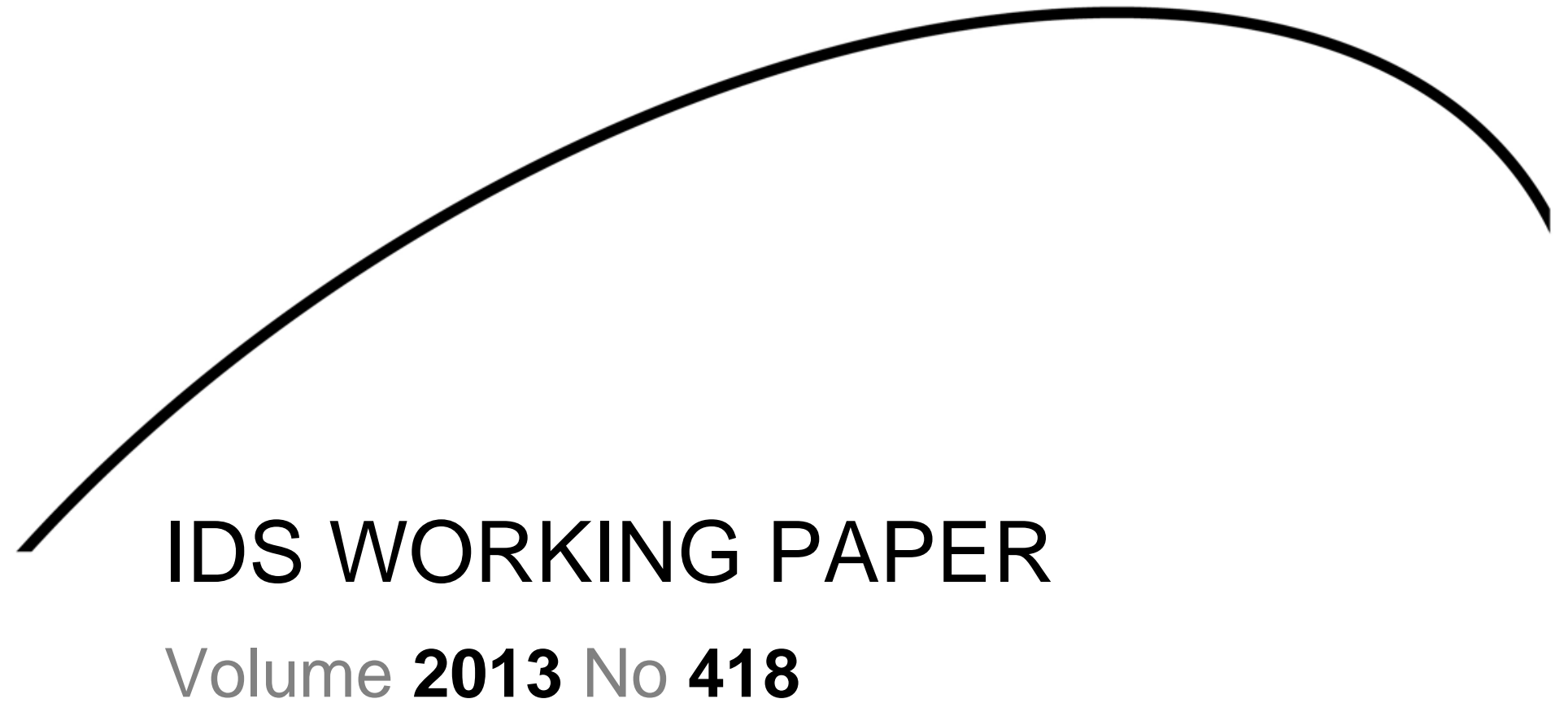

\title{
Rent Management - The Heart of Green Industrial Policy
}

Hubert Schmitz, Oliver Johnson and Tilman Altenburg

April 2013

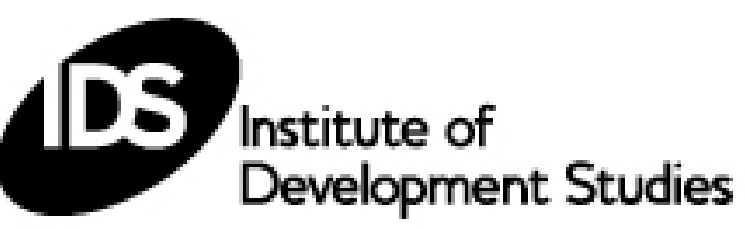


Rent Management - The Heart of Green Industrial Policy Hubert Schmitz, Oliver Johnson and Tilman Altenburg

IDS Working Paper 418

First published by the Institute of Development Studies in April 2013

(C) Institute of Development Studies 2013

ISSN: 2040-0209 ISBN: 978-1-78118-109-6

A catalogue record for this publication is available from the British Library.

All rights reserved. Reproduction, copy, transmission, or translation of any part of this publication may be made only under the following conditions:

- with the prior permission of the publisher; or

- with a licence from the Copyright Licensing Agency Ltd., 90 Tottenham Court Road, London, W1P 9HE, UK,

or from another national licensing agency; or

- under the terms set out below.

This publication is copyright, but may be reproduced by any method without fee for teaching or nonprofit purposes, but not for resale. Formal permission is required for all such uses, but normally will be granted immediately. For copying in any other circumstances, or for reuse in other publications, or for translation or adaptation, prior written permission must be obtained from the publisher and a fee may be payable.

Available from:

Communications Unit, Institute of Development Studies, Brighton BN1 9RE, UK

Tel: +44 (0) 1273915637 Fax: +44 (0) 1273621202

E-mail: bookshop@ids.ac.uk

Web: www.ids.ac.uk/ids/bookshop

IDS is a charitable company limited by guarantee and registered in England (No. 877338) 


\title{
Rent Management - The Heart of Green Industrial Policy
}

\author{
Hubert Schmitz, Oliver Johnson and Tilman Altenburg
}

\section{Summary}

At the heart of green industrial policy is rent management: government creating and withdrawing opportunities for highly profitable investment. This paper asks what the key factors are for rent management to succeed. Drawing on a range of literatures the paper first deals with the critical success factors for 'normal' rent management and then turns to one of the most pressing and controversial issues of our time: how to bring about the transition to renewable energy. This is extra challenging because technological uncertainties are high, time horizons for investment are long, yet action is required now. The paper suggests that responding to these challenges requires above all a political approach to rent management. The critical success factors for managing such policy rents are those that enable it to mitigate four risks: political capture by private investors and allied policy makers; choosing the wrong instruments; targeting the wrong sectors or technologies; and doing too little. The paper concludes that a public-private-civic alliance is needed to deal with the most fundamental risk of governments doing too little and not achieving the scaling up of green investment.

Keywords: green transformation, green industrial policy, rent management, state business relations, transformational alliances, political economy of climate change

Professor Hubert Schmitz is Fellow of the Institute of Development Studies at the University of Sussex and leads the IDS research programme 'Accelerating the Green Transformation'.

Dr Oliver Johnson, formerly of SPRU - Science and Technology Policy Research, University of Sussex, is researcher at the German Development Institute and specialises in energy reform and low carbon development.

Dr Tilman Altenburg is Head of the Department for Competitiveness and Social Development of the German Development Institute, leading its work on industrial policy and low carbon innovation. 


\section{Contents}

Summary

1 Introduction $\quad 5$

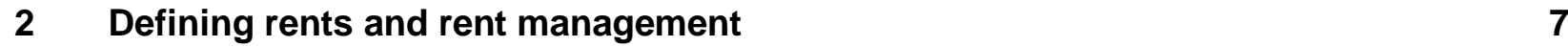

$\begin{array}{llc}3 & \text { Managing rents } & 8\end{array}$

$\begin{array}{llr}4 & \text { Seeking rents } & 9\end{array}$

$5 \quad$ State-business relations $\quad 11$

$6 \quad$ Policy learning and experimentation $\quad 14$

$7 \quad$ Extra challenges for green rent management 16

$\begin{array}{ll}7.1 \text { Urgency } & 16\end{array}$

7.2 Uncertainty 16

$\begin{array}{ll}7.3 & \text { Long time horizons } \\ 7.4 & 17\end{array}$

$\begin{array}{lll}7.4 & \text { Market failures } & 18\end{array}$

$\begin{array}{lll}7.5 & \text { Towards a political approach to rent management } & 18\end{array}$

$\begin{array}{ll}7.6 & \text { Transformative alliances } \\ \end{array}$

8 Conclusion $\quad 21$

8.1 Dealing with the risk of political capture 21

8.2 Dealing with the risk of adopting the wrong instruments 22

8.3 Dealing with the risk of targeting the wrong sectors or technologies 22

8.4 Dealing with the risk of doing too little 22

8.5 Future research 23

$\begin{array}{ll}\text { References } & 24\end{array}$

Table

Table 5.1 Public-private alliances: factors contributing to positive outcomes 


\section{Introduction}

There is increasing agreement that mitigating climate change requires intervention by the state. There is, however, no agreement on how best to intervene. What is the most promising approach? Under what political conditions can it work? How can these conditions be enhanced? What capabilities - within government and outside government - are needed to make it work? Which instruments are most appropriate? How big an intervention is needed to correct the market failure? How long should the policy be in operation? These are the policy questions which arise at the national level. ${ }^{1}$

The search for answers to these questions needs take account of several risks: doing too little would mean that we reach a tipping point ${ }^{2}$ beyond which damage to the global ecosystem becomes irreversible. Doing too much would mean moving in the right direction but in a wasteful way. Doing the wrong things can harm rather than further progress. Getting it right is not about technical optimisation but about political management under great uncertainty. This paper seeks to identify the key factors which help it to succeed.

Let us specify our objective more precisely. This paper is a contribution to the debate on green industrial policy which we define as 'government intervention which brings about economic restructuring without overstretching the carrying capacity of the global ecosystem'. We are particularly concerned with our planet's capacity to cope with carbon emissions since these induce climate chaos. We can therefore - for the purpose of this paper - adopt a narrower definition of green industrial policy, namely 'government-induced restructuring towards a low carbon economy', 3

While many issues in the debate on such green industrial policy are contested, there is agreement on two things: first, reducing reliance on fossil fuels and increasing the role of renewable energy is central to reducing carbon emissions and mitigating climate change. Second, attracting private investment to the development and deployment of renewable energy technologies ${ }^{4}$ is essential for achieving this. Government can do this by providing (and withdrawing) opportunities for above-average profits on investment. We call this rent management, following Khan (2008). This rent management is always a challenging task and it is particularly challenging when it comes to decarbonisation: the uncertainties are high and the time horizons are long, yet investments need to be made now. This is the first big transition in history that has a deadline.

The aim of this paper is to help understand rent management - both in general when aimed at industrial restructuring and specifically when aimed at fostering renewables. As will become apparent in the course of this paper, there is no golden path or silver bullet, but there are concepts and tools which help to identify disabling and enabling factors for good rent management. Identifying these is important for policy learning and experimentation which - as we shall argue - are important for the transition to renewable energy. In pursuing our objectives, we will draw in particular on the literature concerned with managing and seeking rents. For further inspiration, we draw on other literature, in particular works concerned with state-business relations, industrial policy and policy experimentation, and bring in lessons from recent studies of the green transformation and sustainability oriented innovation systems.

For a discussion of policy challenges at the global level, see Bulkeley and Newell (2010).

For a discussion of tipping points in the green transformation, see WGBU (2011).

A similar definition is used by Karp and Stevenson (2012): 'government attempts to hasten the development of lowcarbon alternatives to fossil fuels'.

For the sake of brevity, the remainder of the paper will refer to this as 'fostering renewables'. 
The question which drives this paper is what are the critical success factors for green rent management. Identifying such factors in government is essential but not sufficient; we also look for success factors outside government. Success means pushing up private green investment in an effective and efficient way. This paper does not, however, focus on measuring the outcome (notoriously difficult because of the missing counterfactual) but on getting the process of restructuring underway and triggering a self-reinforcing dynamic.

The paper is organised as follows: Section 2 prepares the ground by providing a definition and typology of rents and making clear that this paper is about policy rents. The substantial discussion begins with Section 3; it puts government in the driving seat and squeezes those elements out of the rent management literature which are useful for our purpose. The basic idea of this literature is simple: in order to bring about economic transformation government needs to direct private investment into new sectors. This is done by offering investors the possibility of above average profits. It involves creating and allocating rents among different actors. The capabilities required for effective rent management are discussed in this section. Subsequent sections then draw on other strands of research to complement the insights gained from the literature on rent management.

One of the big challenges for rent management is that the target group, the private investors, do not necessarily 'follow the script', for example, putting more effort into obtaining incentives than developing or deploying the new technology. Such problems have been discussed at length in the rent seeking (and principal-agent) literature. Section 4 distils those insights from the rent seeking literature which can help to make rent management more effective. There is a deliberate tension between Sections 3 and 4: the rent management literature starts from the position that rents need to be created in order to channel investments into desirable sectors and is concerned with the conditions to make this happen. In contrast, the rent seeking literature emphasises the risk of perverse incentives and political capture and therefore argues that rent regimes should be avoided. At the risk of oversimplification, one could say that the rent management literature starts from the assumption that rent is a good thing and that the challenge is to manage it well. In contrast the rent seeking literature starts from the assumption that rent is a bad thing and that rent needs to be minimised if not eliminated. Working through this tension helps us to identify critical success factors but it is not sufficient.

There are three dimensions which remain underdeveloped in the literature on managing and seeking rents and which need explicit consideration. These three dimensions are interrelated but will be discussed one by one.

- Alignment of interests: we need to take into account not only the interests of the private investors but also the interests of the political leaders and policy makers. This is why Section 5 draws on the state-business literature and identifies concepts which capture different kinds of interests and alliances and the political conditions for transformational outcomes. These conditions lie partly within and partly outside government.

- Policy learning and experimentation: governments seeking to accelerate the transition to renewable energy cannot follow tested pathways but they are under pressure to act now. This is why Section 6 explores insights which the policy experimentation literature provides.

- Long time horizons and great uncertainties: fostering renewables requires mobilising enormous investments with long time horizons, channelling these investments into pathways that are often poorly defined, yet seeking to accelerate the process because of looming deadlines. Section 7 therefore asks how green rent management differs from 'normal' rent management and what extra requirements are needed to make it work. To this end it draws on recent work concerned with fostering the green transformation and building sustainability oriented innovation systems. 
The final Section 8 draws together the key factors which contribute to successful green rent management. It groups the risks and challenges and then identifies how these can be overcome. The paper finishes with questions for future research.

\section{Defining rents and rent management}

There is no agreed definition, nor is there an agreed typology of rents. The conceptual steps we take in this paper are as follows:

1. We define rents as above average profits.

2. We distinguish between three types of rent:

- Rents made possible by nature: this includes Ricardo's ground rent and more generally rents derived from mining natural resources.

- Rents made possible by private enterprises creating and taking advantage of barriers to entry. The most famous example is Schumpeter's innovation rent. Intellectual property rights are a way of prolonging and protecting this rent. But there other ways in which firms create temporary barriers to entry and earn rents - see for example Kaplinsky's (2005) list of nine rents.

- Rents made possible by public policy. The best known example is trade policy rent, made possible by government imposing tariffs on foreign imports or providing subsidies for national producers.

In this paper we are concerned with the last category, namely rents made possible by government intervention. We will refer to them as 'policy rents' and define them as riskadjusted $^{5}$ above average profits ${ }^{6}$ made possible by government intervention. Continuing with our conceptual steps we can define rent management as government intervention for raising (lowering) profitability in selected sectors and thus making private investment in these sectors more (less) attractive. ${ }^{7}$ In this paper rent management refers to the way governments create or withdraw policy rents and how they influence their allocation among different actors and for different purposes.

Neither the above definitions nor typology appear in the rent management literature but they are entirely in the spirit of that literature. The next section extracts those elements of this literature which might be useful for our purpose of how to bring about the transition from fossil fuels to renewable energies.

6 Determining the average rate of profit is difficult but this is an empirical not a conceptual issue. The empirical problem arises from the fact that profit expectations vary. Similarly, risk perceptions vary a great deal.

In other words, rent management is incentives management. 


\section{Managing rents}

The inspiration for this paper comes from the small literature on rent management (Medema 1991; Khan 2008; Khan and Blankenburg 2009). We give particular attention to the work of Mushtaq Khan because his central concerns are the same as ours. He seeks to understand economic transformation and the role of government in bringing it about. The analytical issues are the same, even though we are concerned with the contemporary green transformation while Khan goes back in time analysing the transformation of developing countries from low productivity pre-capitalist to higher productivity capitalist ones (Khan 2008: 126).

Khan asks what kind of governance capabilities enabled developing countries to make this transformation. His main argument is that the transformation was not achieved by relying on market enhancing governance as advocated in the good governance and investment climate debate. Although he is not against this horizontal approach aimed at making markets more efficient and reducing transaction costs for all enterprises, he argues that it provides at best second order conditions. Instead, what we call a vertical approach is needed, providing incentives for investment in specific new sectors. To do this, government needs capabilities to increase profitability in new sectors and decrease profitability in old sectors. This kind of capability - Khan argues - has been essential for the earlier transition to capitalism and for the more recent economic transformation which enabled Asian developing countries to compete in the global economy. In a nutshell, fostering economic growth and transformation requires government acquiring and using rent management capabilities.

Our most important lessons from the rent management literature are as follows: first, the challenge is not to avoid rents but to manage them; second, the capabilities required for managing rents need attention; third, capable governments can use a range of instruments; fourth, identifying the political conditions for successful rent management is important - but needs help from other strands of literature.

These points can be derived from Khan's review of the experience of developing countries in the second half of the twentieth century. He observes that economic transformation was an ambition of many countries.

Successes and failures ... can be related to the match or mismatch of the requirements of the economic strategy being followed and the governance capabilities that were required for effectively implementing it.

(Khan, 2008: 111)

Capabilities to carry out market-enhancing policies (such as investment climate reform) were not enough. Rent management capabilities were necessary. This is an important conclusion in view of the insistence of some international (and national) development agencies that developing countries should limit themselves to reforming their investment climate and that more efficiently working markets would then bring about the required transformation.

Khan concludes from his historical review that the Asian governments with the requisite rent management capabilities have used very different instruments.

Opportunities were created using many different mechanisms including tariff protection (in virtually every case but to varying extent), direct subsidies (in particular in South Korea), subsidized and prioritized infrastructure for priority sectors (in China and Malaysia), and subsidizing the licensing of advanced foreign technologies (in Taiwan). With the advent of a new consensus on international trade through the WTO, tariff protection is no longer an option for most developing countries, but 
historical experience tells us that this is not the only way, or even the most effective way in which to organize support for the learning processes ....

(Khan 2008: 134).

Implicitly Khan argues that searching for the best instrument (best in all circumstances) is futile, again an important point to consider for the debate on fostering renewables.

While emphasising the variety of instruments, there is a common capability requirement for rent management. '... states had the institutional and political capacity to ensure that nonperformance was not tolerated for too long. ... The common feature of success was that failure led to corrective action' (Khan 2008: 134-5).

This emphasis on the capability requirements of rent management is reinforced by the warning that 'badly managed rents can mean permanently poor resource allocation as well as high rent-seeking costs' (Khan 2008: 135). '... potentially growth-enhancing rents can become growth reducing if the rent-management capacities of the state are missing (Khan and Blankenburg 2009: 348). The rent management literature tells us, however, little about how these capabilities are acquired. While concerned with fostering learning in the private sector, it ignores the issue of learning in government. This is why we examine later - in section 6 - what can be extracted from the literature on policy learning and experimentation that is useful for our purposes.

The rent management literature does, however, draw attention to the political conditions needed for effective rent management. Managing rents 'is not just constrained by state capacities, but also and often primarily by political constraints that prevent specific strategies of rent management from being implemented' (Khan and Blankenburg 2009: 348). The authors emphasise that the successful rent managers have emerged in different political circumstances. 'While their internal political configurations were different, each of these configurations allowed the effective implementation of different and quite specific strategies of rent management' (Khan and Blankenburg 2009: 348). This lesson was derived from a review of Latin American and Asian experiences. The conclusion that the enabling political configurations varied a great deal is important in itself but it begs the question of whether there were common elements and whether the key political elements for successful rent management can be specified. The rent management literature itself does not provide these. Therefore section 5 will turn to the state business relations literature and seek support from there.

Specifying the political conditions for successful rent management is particularly important because the provision of rents can be (and often is) abused by the private sector. This danger is dealt with at great length in the literature on rent seeking enterprises. The next section distils what public rent managers can learn from this literature.

\section{Seeking rents}

Managing rents effectively requires understanding the interests and objectives of actors who seek to obtain those rents. The rent seeking literature helps to bring these out. In fact enormous attention has been given by economists and political scientists to rent seeking and the harm it does to the economy and polity (Congleton et al. 2008; Tullock 2005). For the purpose of this paper it suffices to bring out two key points:

- Chasing the investment incentives becomes the main entrepreneurial activity rather than competing by making better products or adopting better processes. The offer or 
possibility of policy rents pulls entrepreneurs into unproductive activities. This was Krueger's (1974) main argument in an article which triggered the rent seeking debate.

- Groups of entrepreneurs 'capture' government such that their interests are prioritised over the interests of others in the rent allocation process. As a result incentives are given for the wrong things or they are too high for the right things. Such political capture by business of the policy process is difficult to reverse.

Some authors have used a principal-agent framework in order to work through such problems and finds ways of addressing them (Tollinson 1982). The rent producing 'principal' delegates responsibility for achieving a particular goal to a rent seeking 'agent'. Problems arise because principals and agents naturally have conflicting interests and the principal can never fully know what the agent is doing. As a result, the agents will only pursue the principal's interests if they have an incentive to do so and the principal can only confirm this by monitoring their agent. Monitoring schemes and the creation of incentive structures come at a price. It is in the interests of the agent to influence the priorities and knowledge of the principal through the strategic use of information (and disinformation) and manipulate the way a particular issue is framed in the policy process. Meanwhile, the principal will have to spend resources to obtain a variety of knowledge upon which to base decisions about the optimal level of rents. For example, in the case of subsidising deployment of renewable energy policy, governments try to set rents at a level that will ensure the desired level of investments into renewable energy projects. Determining this level is a complex task; it requires making a judgement of scientists' predictions, consumer preferences and investors' cost data.

Striking a balance between costs and benefits is a challenge and offers many opportunities for rent seeking agents to influence the allocation of rent (Hepburn 2010: 127-28). The implication for the rent managers (principals) is that they need to invest in obtaining independent information to monitor the agents and assess competing claims. This need for monitoring the agents (rent seekers) is directly relevant for our central concern: identifying the critical success factors for rent management.

Organising this monitoring is costly but it can be done and often needs to be done. But it would not be an adequate response if the relationship between government (principals) and investors (agents) has become too close and the government is in the investors' pocket. This is the problem of political capture. The rent -literature helps us to recognise this problem and its severity but it does not offer a way out. It merely suggests that rents should not be created to start with. In this way the problems arising from rent seeking would be avoided.

There are two problems with this position: first it fails to recognise that rents are ubiquitous. The energy sector is a perfect example. Avoiding the creation of rents for producing renewable energy would not take us into a rent free world. On the contrary, the evolution of the fossil fuel industry is riddled with creation and allocation of rents ... and with political capture.

Second, rents are not necessarily harmful. They can be a strategic transformational resource. If government wants to enlist the private sector in restructuring the economy, rent management is an unavoidable task. This is why we ask what other bodies of literature offer in terms of critical success factors for rent management. To this end, the next two sections screen the state-business literature and the literature on policy learning and experimentation. 


\section{State-business relations}

The purpose of this section is to specify what kind of state-business relations are conducive to successful rent management. It identifies the main propositions in the state-business literature relevant for our concerns.

There is now widespread agreement that conducting industrial policy requires 'embedded autonomy' (Evans 1995). In other words, government needs to work with the private sector but must avoid capture by the private sector. The Weberian ideal of a civil service detached from business is unlikely to work; civil servants do not have the expertise and up to date knowledge for designing and implementing industrial policy. This view is expressed by Rodrik (2007), Abdel-Latif and Schmitz (2010), Altenburg (2011) and many others.

If active cooperation between government and business is so critical, we need to ask what interests would bring them together. On both the private and public sector side we need to distinguish between short term and long term interests. The short term interests of the private sector are discussed in the rent seeking literature ${ }^{8}$ but the long term interests receive little attention. They are however well known: some entrepreneurs take the long view and incur high short term costs (investing in new technologies) in order to position themselves for the future.

On the public sector side, the distinction between short term and long term interests is equally important - as stressed by Olson (1993). There are politicians/policy makers who seek immediate benefits (personal enrichment by providing favours; improving their prospects at the next election) and those who seek benefit in the long term (gain from growth of the economy or the sector over several years). ${ }^{9}$ Where both private and public actors are driven by the long term interests, one would have an ideal constellation for successful rent management. However, turning this into a necessary condition would be too restrictive and prevent us from looking for second best solutions.

The real world is messy and public office is no exception. We therefore suggest a three-fold categorisation of the interests of holders of public office:

a) idealism, altruism of the 'public servant';

b) legitimate own interests - promotion, re-election, prestige;

c) illegitimate own interests - corruption, favouritism.

It seems plausible to suggest that first, the promotion of renewables is driven by a combination of these three motives and second, where motivations of the c) category play a big role and become publicly known, rent management is less likely to succeed. However, what holders of public office can get away with varies with institutional and cultural traditions.

Banking on getting away with it is not good enough for our purpose of identifying the critical success factors for rent management. We therefore need to ask whether there are ways of offering targeted incentives for structural change without running into problems of illegitimate enrichment. The traditional rent seeking literature envisages little chance of doing this and is

Harmful rent seeking tends to be driven by short term interests but can also be influenced by longer term interests.

Olson (1993) used the distinction between 'roving' and 'stationary' bandits for this purpose but the term 'bandit' implies a money-grabbing motive which may or may not apply. In many cases, the policy makers' interest lies in obtaining promotion or re-election. Being associated with a successful policy initiative can enhance the prospects of fulfilling this legitimate ambition. 
therefore against active cooperation between government and business. ${ }^{10}$ Such fundamentalism however was challenged by those analysts who tried to understand why the newly industrialising countries - in particular those in Asia - were so successful in the $1970 \mathrm{~s} / 80 \mathrm{~s} / 90 \mathrm{~s}$. They found that the state played a major role in the growth and transformation of these economies and that close relationships with the private sector were critical for the effectiveness of these states (Amsden 1989; Evans 1995). These experiences led Schneider and Maxfield (1997) to take stock and bring about a useful shift in the research agenda from whether to under what conditions close relationships between policy makers and investors have a positive effect. On the business side, they highlight the features of the business association (How encompassing is it? Does it monitor and sanction the behavior of members?). On the government side, they highlight the features of the bureaucracy (meritocratic recruitment and promotion and including career incentives to engage with business). Then they add contextual factors conducive to forging close relationships and positive outcomes, notably market threats (competitive pressure) and political threats (to the country or the party in power).

This identification of conducive factors is helpful for our purposes. State business relations characterised by formal relationships between a meritocratic bureaucracy on the one hand and an inclusive business association contribute to good rent management. But do we want to elevate this kind of state-business relation into a necessary condition for successful rent management? Posing this question means entering the murky world in which the benefits of meritocracy and transparency are recognised but not always practised and in which informal relationships matter more than formal relationships. It is these features which characterise a large part of the real world - though to different degrees.

There are recent studies which have examined the informal and transitional relations between state and business and enquired into the outcomes. The relevance of such informal and transitional relationships comes out strongly in a study on the politics of investment and growth in Egypt (before the revolution). It shows that even in a country where rent seeking is widespread, effective public-private alliances can emerge focused on fostering the growth of specific sectors. Abdel-Latif and Schmitz (2011) conclude that state-business relations where they are driven by common interest and informed by common understanding of problems - played an important role in directing private investment into a new sector and restructuring an old sector. Concerned with the potential for abuse, they list six factors which influence whether such public-private alliances have the sought after transformational effect or are abused for individual enrichment. While not tested in their own empirical work, these factors are directly relevant for our purposes. 
Table 5.1 Public-private alliances: factors contributing to positive outcomes

\begin{tabular}{|l|l|}
\hline Factor & Effect \\
\hline $\begin{array}{l}\text { Organisational } \\
\text { capacity of the } \\
\text { private sector }\end{array}$ & $\begin{array}{l}\text { High organisational capacity of the private sector and broad-based } \\
\text { membership of its association increases the likelihood of an } \\
\text { alliance becoming effective and legitimate. }\end{array}$ \\
\hline $\begin{array}{l}\text { Upward } \\
\text { accountability of } \\
\text { policy makers }\end{array}$ & $\begin{array}{l}\text { Accountability and promotion linked to carbon emission-reducing } \\
\text { performance increases the likelihood of policy makers engaging in } \\
\text { low-carbon alliances with the private sector. }\end{array}$ \\
\hline Competitive pressure & $\begin{array}{l}\text { Abuse of public-private alliance is less likely when protection of } \\
\text { internal markets is low. }\end{array}$ \\
\hline $\begin{array}{l}\text { Monitoring of sectoral } \\
\text { performance }\end{array}$ & $\begin{array}{l}\text { Open access to key performance indicators and regular monitoring } \\
\text { reduce the likelihood of public-private alliances being abused for } \\
\text { private gains. }\end{array}$ \\
\hline $\begin{array}{l}\text { Consumer protection } \\
\text { laws and agencies }\end{array}$ & $\begin{array}{l}\text { Consumer protection laws and consumer protection agencies } \\
\text { reduce the likelihood of public-private alliances taking initiatives } \\
\text { which harm the public. }\end{array}$ \\
\hline Freedom of the press & $\begin{array}{l}\text { A free and inquisitive press and media reduce the risk of public- } \\
\text { private alliances being used for personal enrichment. }\end{array}$ \\
\hline
\end{tabular}

Source: Adapted from Abdel-Latif and Schmitz (2011).

The factors identified in Table 5.1 amount to an eclectic list. It includes factors which concern the organisation of the private sector, the public sector, the economy (by sector), and civil society. None of these factors in isolation will be sufficient to make rent management effective: they work in conjunction. We are not saying, however, all of the factors must apply in order to achieve the desired outcome.

In conclusion, the overall lessons from the state-business literature are that:

- Some of the critical success factors lie outside the state apparatus. ${ }^{11}$

- Transformative rent management requires alignments of interest across the public-private divide.

- The abuse of such alliances for illegitimate purposes can be curtailed through a combination of ways involving monitoring and pressure. ${ }^{12}$

In a companion piece we concentrate on critical success factors within government, notably the government capabilities needed for successful rent management (see Altenburg et al. 2013).

12 The principal-agent approach to rent management comes to the same conclusion regarding the need for monitoring. It can be seen to provide a more direct route to understanding and improving the allocation and distribution of rents. The state-business literature and the focus on alliances is however more useful on the issue of creating rents and finding solutions to complex collective action problems - as seen later in Section 7. 


\section{Policy learning and experimentation}

Recall that the reason for rent managers seeking to work with the private sector is that they need to explore what to do. There is no golden pathway. There is no best instrument that suits all conditions. Section 3 stressed that that rent management can use a variety of instruments. This section asks how government acquires the capabilities to select and implement policies and learns from successes and failures. This is particularly relevant for rent management focused on new green sectors.

The emphasis on exploring, discovering, learning and experimenting is relatively recent in the industrial policy literature. It has been stressed particularly forcefully by Rodrik:

The right model for industrial policy is not that of an autonomous government applying Pigovian taxes or subsidies, but of strategic collaboration between the private sector and the government with the aim of uncovering where the most significant obstacles to restructuring lie and what type of interventions are most likely to remove them. Correspondingly, the analysis of industrial policy needs to focus not on the policy outcomes-which are inherently unknowable ex ante-but on getting the policy process right. We need to worry about how we design a setting in which private and public actors come together to solve problems in the productive sphere, each side learning about the opportunities and constraints faced by the other... Hence the right way of thinking of industrial policy is as a discovery process-one where firms and the government learn about underlying costs and opportunities and engage in strategic coordination. The traditional arguments against industrial policy lose much of their force when we view industrial policy in these terms... Yes, the government needs to maintain its autonomy from private interests. But it can elicit useful information from the private sector only when it is engaged in an ongoing relationship with it.

(Rodrik 2007:101)

We have quoted Rodrik at length because this perspective is highly relevant for rent management aimed at fostering the renewable sectors. The uncertainties are enormous and both government and business are engaged in a discovery process which we need to understand.

There is of course international learning (from other countries) but it is not sufficient. While endless research and consultancy papers are written about policy lessons for or from other countries, the successful economic transformations in history have one thing in common: each country found its own way forward. This point was made a long time ago by the historian Alexander Gerschenkron. In his book Economic Backwardness in Historical Perspective (1962) he argued that latecomers have to plot their own distinctive path of transformation. Repeating what others have tried before is rarely possible because each country has its own specific internal conditions and because the rise of the early developer changes the external conditions for the latecomer. Analysis of early industrialisation in continental Europe led Gerschenkron to this conclusion. Analysis of economic transformation in East Asia leads to the same conclusion. Japan, Korea, Malaysia, Taiwan and China did not follow models from elsewhere. In 'Institutions and Growth in East Asia', Stephan Haggard (2004) emphasised how East Asia succeeded through a long process of 'transition' that was highly experimental in nature. Similarly, Mike Hobday (2003), in a review of Asian industrial development, concludes that it is diversity rather than uniformity in the institutional arrangements and development policy that characterises the innovation experience of the Asian Tigers.

In short, the institutional configurations of the successful transformers varied a great deal; they had taken different routes and used different instruments. This does not amount to an 
argument against learning from each other's successes and mistakes. It is however an argument for starting with one's own internal and external circumstances. This seems an important conclusion for the green transformation project. It provides the starting point for the discovery process, experimentation and policy learning stressed by Rodrik (2007).

The question then is whether we can distinguish between different ways of organising the learning process. An essential distinction is that between centralised and decentralised rent regimes. Countries in which all or part of the rent management is delegated to sub-national governments have a much bigger laboratory. Good examples are Germany, India and China which have a history of decentralised industrial policy. Such decentralised settings offer a greater learning potential for three reasons: each state or province can conduct its own policy, competition between states/provinces accelerates the learning, and the laggards can learn from the advanced rent managers. Intra-country learning is easier to organise than inter-country learning because common framework conditions apply.

We need, however, to take into account that there are counterarguments. Hongbin Cai and Triesman $(2006,2009)$ contradict the proposition that decentralisation enhances policy experimentation; their counterarguments are based on modeling work and empirical research in China. In contrast, Heilmann (2008) suggested that decentralisation contributes to policy experimentation in China. Similarly, Schmitz et al. (2012) conclude that decentralisation had a positive effect in Vietnam. The rapid economic transformation of Vietnam benefited from experimentation that went on in the provinces. The provinces were laboratories some of which generated insights that were used in other provinces and by the Centre. Further support comes from Altenburg and Engelmeier (2012) who conclude that rent management for solar energy in India has worked well because under the umbrella of the National Solar Mission there was scope for experimentation and policy learning in various Indian states. So there is a plausible case for distinguishing between policy learning in centralised and decentralised rent regimes. But for our concerns it is not sufficient to ask whether decentralising rent management enhances policy learning; we need to ask under what conditions it does so. Decentralised systems have bigger laboratories for experimentation, but experimentation does not guarantee policy learning. For this to happen, institutional arrangements are needed that assess experiments and extract policy lessons.

To conclude, for rent management to succeed it needs to take into account that:

- There is no golden pathway for accelerating the transition to renewable energy. Each country needs to find its own way forward.

- Learning from the experiences of other countries is useful but replication rarely works. Starting from the country's own conditions is paramount.

- Experimenting is essential. Working with the private sector is important for experiments to succeed.

- In decentralised political systems it is easier to organise experimentation but the transmission belt to policy learning needs further research. 


\section{Extra challenges for green rent management}

The previous sections have highlighted factors that contribute to the success of rent management. They apply to rent management in general - whatever sectoral shift it seeks to bring about. This section asks why accelerating the shift from a high to a low carbon economy involves extra challenges and suggests four inter-connected reasons: (1) urgency of action, (2) long time horizons, (3) high uncertainties, and (4) unprecedented market failures (Altenburg and Pegels 2012). It then discusses why a more political approach is needed for green rent management and why public-private-civic alliances are critical for it to succeed.

\subsection{Urgency}

The urgency comes from the prediction of irreversible damage. Continuing with business as usual has costs that are almost impossible to calculate but certainly higher than making low carbon investments now. Climate scientists warn us that decarbonisation has to be achieved within a very short time frame if severe environmental damages are to be avoided. According to Stern (2009), $\mathrm{CO}_{2}$ concentrations in the atmosphere need to be kept below 500 parts per million (ppm) if we want to maintain a 50 per cent chance of keeping global warming below $2^{\circ} \mathrm{C}$. The more we move beyond this level, the higher the risks of environmental tipping points beyond which self-reinforcing and largely irreversible mechanisms start off, e.g. when permafrost soils start thawing releasing large quantities of methane gas; when polar caps melt and sea water levels rise; or when the ecosystem of the Amazon's tropical rainforests collapses. If no action is taken, around $750 \mathrm{ppm}$ will be reached by the end of the century, causing an increase of the global mean temperature estimated at $5^{\circ} \mathrm{C}$ relative to preindustrial levels (Stern 2009).

In other words, the green transformation is the first transformation in human history that has a deadline - and a very ambitious one. To keep this deadline, bold action needs to be taken immediately. According to IPCC (2007), WBGU (2011) and other research groups, greenhouse gas emissions need to decline before 2020 if the $2^{\circ} \mathrm{C}$-target is to be reached. However at the time of writing (late 2012), emissions continue to increase. There is agreement that a switch in the source of energy is an essential component of a turn around. Helm (2012) argues that in considering this switch too much attention is given to the choice between fossil fuels and renewables and not enough to the choice between different types of fossil fuel. 'Getting out of coal is an absolute and immediate priority' and gas (whose carbon emissions are half that of coal) can play an important transitional role (Helm 2012:10). We agree with this, but would stress that investing in renewable energy now is essential for achieving more dramatic reductions later. While scenarios for the transition towards a sustainable global energy regime differ (e.g. IEA 2011; WBGU 2011), they have in common that they see the deployment of renewable energy technology as one of the main contributors to emissions reductions (besides energy efficiency technologies). While fiercely contested by vested interests until a few years ago (Blasberg and Kohlenberg 2012), the margins of scientific disagreement concerning the urgency of public action have shrunk considerably over more recent years.

\subsection{Uncertainty}

The problem for rent management is that - in order to succeed - it needs to focus on specific sectors and subsectors and use specific instruments aimed at developing and deploying specific technologies. It is at this level that uncertainties are high. The reasons are two-fold: 
First, there is uncertainty with regard to the right choice of technologies. Different renewable energy sources - from biomass to wind, solar and geothermal - need to be combined to achieve a reliable energy mix; also, different technologies need to be chosen for different purposes, e.g. solar photovoltaics may be appropriate for local supply, whereas concentrating solar power (CSP) plants allow for energy storage. At the same time, it is not clear how rapidly the costs of different technologies diminish and, therefore, what the most cost-effective energy mix will be in the future in any given country or location, especially if costs of energy distribution and storage are accounted for. In the same vein, some technologies may have important co-benefits that make them more attractive than others, such as job creation or knowledge spillovers into other industries. Overall, current market prices are a poor predictor of investment needs, as they cannot fully reflect important parameters of the energy systems of the future, such as the long-term availability of different energy sources or the optimal energy mix for specific future load curves. Governments thus have to make choices about allocating rents for the development and deployment of different renewable energy technologies on the basis of highly incomplete information.

Second, all these technologies have a range of specific positive or negative implications for different groups of society, and therefore prompt lobbying for and against them. The establishment of hydropower stations, wind and solar parks, overhead transmission lines and other infrastructure investments often encounters local resistance. Similarly conflictive are the conversion of agricultural land into bio-energy plantations and plans for potentially risky elements of new energy systems, such as carbon-capture and storage projects. Renewable energy lobbyists (from industry and NGO) in contrast try to speed up such projects. What shape the energy transition actually takes is therefore strongly dependent on social acceptance, power relations, and political settlements among stakeholder groups - and these may change over time in unpredictable ways. Such political uncertainty obviously affects the government's ability to send out credible signals, e.g. guaranteeing a schedule for grid expansion or a long-term tariff subsidy.

\subsection{Long time horizons}

The uncertainties are exacerbated by the long time horizons needed for new energy systems to become viable. Power plants that are built today are laid out for the next 30 to 40 years. Also, payback periods of grids and storage facilities may stretch over several decades. Making investment decisions today without taking long-term effects into account may therefore lead to lock-in effects (Unruh 2000), because large sunk costs discourage switching to a superior energy system in the future. Furthermore, the full benefits of today's investment can only be reaped many years later. For Germany, a recent energy scenario calculates that the transition to a renewable energy will require additional investments until around 2030 when it will start generating a large and increasing surplus compared to a fossilnuclear energy system (FEE 2010). Such long time horizons however increase the uncertainty, and the risk premium, for investors. Similarly, politicians are unlikely to impose huge additional costs on their current electorate, even when the long-term benefits for their economies are clearly conceivable.

The combination of urgency of action, high uncertainty and long time horizons presents policy makers with a seemingly irresolvable dilemma. Helm has given expression to this dilemma when he questions 'Low Carbon Roadmaps' and 'Energy Roadmaps':

... how can anything useful be said now about the configuration of energy systems in 40 years time? Consider how communications technology has revolutionized not only communications but also economies and social interactions in the last 20 years. Then imagine replicating such change to energy over 40 years - or a century.

(Helm 2011: 524) 
The danger with such arguments is that they provide ammunition for doing nothing. The problem is that not intervening and relying on the market produces its own failures, many would say even greater failures with even worse consequences. While not a researchable proposition, it is important to make these market failures explicit.

\subsection{Market failures}

Stern (2007) has famously declared that climate change is the result of the biggest market failure of all time. While the scale might indeed be unprecedented, the types of market failures are not new.

- Environmental costs are not reflected in prices. This is an old problem which has now particularly severe consequences. Producers and consumers do not pay for the carbon emissions caused by their production/consumption. Hence there is no economic incentive for changing what they make or consume. What is new is that the damage caused has global rather than merely local consequences as can be seen by the increasing incidence of extreme weather conditions occurring simultaneously in different parts of the world. Attempts to deal with this by introducing a carbon price have failed as shown notably in the EU Emissions Trading Scheme (Helm 2012).

- Businesses fear that they cannot reap the gains from their high risk green investment. Again this is an old problem but of great relevance for the development of new green technologies. The costs and the risks for the first movers are high providing an incentive to wait and pounce only once others have reduced the margins of uncertainty. The result is underinvestment or delay in investment - even though finance capital is desperate for new investment opportunities. Providing policy rents is a way of countering the lack of or delay in investment.

- Coordination failures slow down investment. This is also a well-known problem. It affects the low carbon energy transition severely because this transition has many systemic features. The viability of investments depends often on the timely occurrence of other investments. For example, off shore wind parks in Germany are currently running into severe financial difficulties because the required grid connections to take the electricity to where it is needed lag far behind. Public infrastructure investments or the provision of rents for private investment are needed to overcome such coordination failures.

In sum, a triple market failure slows down the transition from fossil fuel to renewable energy. In principle, introducing a carbon price, either directly via a carbon tax or indirectly via emissions trading, would be the best way of alleviating such failures but experiments with this approach have failed so far. Other instruments need to be considered in particular the creation and allocation of substantial amounts of policy rents. Given that such rents need to be provided over fairly long periods and under considerable uncertainty, the incentives for rent seeking and the risks of political capture are large. Governments have considerable scope in defining how rapidly they want to internalise environmental costs; how they allocate subsidies between different technologies; and whether they want to provide high subsidies in order to gain early mover advantage or wait and support renewable energy technology only when other countries have driven the initially high costs down. Rent-seekers can use any of these strategic considerations to push for their specific interests.

\subsection{Towards a political approach to rent management}

Given these extra challenges faced by rent management for renewables are there extra insights that help identify the critical success factors? Our main proposition is that the political element occupies an even higher place than in normal rent management. 
Much of the debate promoted by green politicians and activists has relied on the argument that there is a deadline for public action. Not meeting the deadline would be punished with ever great climate chaos and worsening living conditions for future generations. This scenario of doom and gloom is not working. In spite of its scientific basis, it has not generated the required political support.

The work of the WGBU (German Advisory Council for Global Change) underlines the relevance of working on the political dimension of rent management. The clearest manifestation is its 2011 report World in Transition - A Social Contract for Sustainability. The central message of this report is that the technological potential for comprehensive decarbonisation is available and the policy instruments needed are widely known. 'Now, it is first and foremost a political task to overcome the barriers of such a transformation, and to accelerate the change.' (WGBU 2011: 1). Central to this political task - according to the Council - is the forging of 'a social contract for sustainability'. What is meant here is a contract between the state and the citizens. 'The contract has to bring two important new protagonists into the equation: the self-organised civil society and the community of scientific experts' (page 8).

The German Council has been widely criticised for its views on the political drivers of the transformation (for example von Weizsäcker 2011). In our view, however, the political turn of the Council is a move in the right direction. Our main criticism is that a state-civic nexus is not sufficient. Business needs to be included explicitly, thus turning attention to the role of state-business-civic alliances.

\subsection{Transformative alliances}

Focusing on alliances and including business in such alliances is critical for two reasons. First, recent political science analysis shows that alliances (or coalitions) can be effective in overcoming complex collective action problems (Leftwich 2009; Peiffer 2012). Second, including business in the analysis and formation of alliances makes a significant difference. Maxfield (1991: 421) stressed long ago the critical role of policy coalitions which cut across state and society and include business. More recently, Abdel-Latif and Schmitz (2010) have shown why and how state-business alliances matter for overcoming bottlenecks in industrial development. When it comes to the green transformation, the inclusion of business seems particularly important. As stressed by Newell and Paterson (2011) 'many capitalists and state elites, for a range of different reasons, now have a political and financial stake in the project of decarbonisation' (page 23) ... 'short or medium term transitions to a low carbon economy will have to be supported (financially and politically) by powerful fractions of capital with a stake in the success of such a project' (page 41).

This is a key point. There are parts of the business community which are keen to support the green transformation but are in fact driven by ambitions in other fields, notably securing energy or building a competitive new industry. ${ }^{13}$ Understanding the political dynamics behind green industrial policy needs to include also those interests which are not green in themselves but support the green cause. Effective cooperation between public and private actors does not require that the players support renewables for the same reasons. On the contrary, the chance of effective cooperation increases dramatically if players with different motivations (climate change, energy security, competitiveness, green jobs) are brought into the picture.

The implication is that 'building transformative alliances' needs to be included in our list of critical success factors for green rent management. Building such alliances is different from

Evidence for this proposition comes from on-going research projects of the German Development Institute (Low Carbon Innovation Policies in China, India and South Africa) and Institute of Development Studies (The Political Economy of Low Carbon Investment). 
'building consensus' which is conventionally included amongst the capabilities needed for industrial policy (Altenburg 2011: 49). Consensus is unlikely in the transition from high to low carbon energy. Opposition from fossil-fuel related interests is likely to remain strong as they seek to protect their assets. ${ }^{14}$ Investments in low carbon industries can be counted in billions and are rising but the value of capital assets and intellectual property of the high carbon industry amounts to trillions of Euros. ${ }^{15}$ Low carbon rent management cannot escape from this fact. In this scenario, building alliances is essential for making a transformative impact. Harrison and Kostka (2012) show that in both China and India the state plays a role in building the support base for its low carbon policies through processes which they describe as the bundling of policies and interests.

Resistance comes not just from business interests related to fossil fuels. In some countries resistance comes also from civil society protesting against infrastructure projects or windfarms in particular neighbourhoods (the NIMBY problem = not in my backyard); and it comes from parts of government that regard as incompatible achieving both financial sustainability (reducing indebtedness in the current financial crisis) and environmental sustainability. Rent management for renewables is an intensely contested political process.

In order to maintain legitimacy for creating substantial rents, care in the allocation and distribution of rents is essential. This includes reviews of rent regimes. Such reviews are important because costs come down by margins which are hard to predict. In photovoltaic solar power, each doubling of installed capacity has cut the manufacturing costs of panels by about half, hence subsidies can be reduced. Grid parity with conventional energy is not far off. In other renewables it is taking longer but this can change. The need to review rent regimes for renewables and to acquire the technical capacity to do so is the same as for most other industries. However the political demands on creating, allocating and reviewing rents are probably higher. Acquiring and maintaining this political capacity requires concentrating on reducing carbon emissions while maintaining the support of other players who are in it for different motives.

To conclude this section, the structural transformation required for pushing up the share of renewables in the energy mix cannot rely on the market alone. There is a triple market failure which makes it impossible to break out of the fossil-fuel lock-in. Rent management is both extra important but also extra difficult for three reasons: decarbonisation has a deadline, investments have long time horizons, and the technological uncertainties are high. The combination of these three elements results in the political demands for successful rent management being particularly high. We have argued that the deadlines for reducing carbon emissions have not translated into the required political support, even though the urgency has a strong scientific basis. We have argued that forming and maintaining transformative alliances between state actors, business and civil society are essential for scaling up rent creation to the required level and conducting reviews driven by the decarbonisation targets rather than vested interests. Nevertheless vested interests need to be recognised and are not just a source of problems; they can also be a source of strength. Precisely because rent management for renewables can draw on support not just from the environmental lobby but also from forces primarily concerned with securing energy, building a globally competitive industry and creating green jobs, it can succeed. This creates the political space for applying the more technical and economic tasks of good rent management.

\footnotetext{
14 Renewable energy is on the rise, accounting for 44 per cent of the estimated 208 Gigawatts of capacity added globally in 2011. However, the overall share of renewables in power generation remains at only 6 per cent because of the existing installed capacity of conventional power plants (Moslener 2012).

15 Emphasised by Jonathan Shopley, Managing Director of the Carbon Neutral Company, in seminar on 'Business and Climate Policy' at the Institute of Development Studies on 6 March 2012.
} 


\section{Conclusion}

The creation and allocation of policy rents is the heart of green industrial policy. In this paper we have focused on rent management aimed at developing and deploying renewable energy technologies. In spite of the passions evoked by this agenda, there is little focused attention on the critical success factors of rent management for renewables. This paper has sought to define what rent management is and identify the factors that are critical for it to succeed. This was done by bringing together concepts and distilling insights from several bodies of literature that are related but tend to proceed separately. This final section draws together the key points and highlights issues which require attention in further research.

Whether and how the transition from fossil-based to renewable energies should be accelerated is a highly contested issue. In order to cut through these contestations and summarise the critical success factors, we start by grouping the risks of rent management and then sum up how these risks can be dealt with.

Different sections of the paper have drawn attention to different risks. These risks can be grouped as follows:

- Political capture by private investors and allied policy makers

- Choice of the wrong instruments

- Targeting the wrong sectors or technologies

- Doing too little.

The critical success factors for rent management can be grouped according to how these risks are dealt with.

\subsection{Dealing with the risk of political capture}

The rent management process can be captured by private interests and allied policy makers and be abused for inappropriate ends. This risk receives a lot of attention in the academic debate - as stressed in section 4. It is also prominent in the public debate. The Economist, drawing on Dieter Helm's (2012) The Carbon Crunch, suggested that 'the entire renewables sector ... has become an orgy of rent seeking' (20 October, page 81 ). While exaggerated, the risk of inappropriate rent seeking and political capture is real. We have therefore drawn attention to the multiple ways in which this risk can be contained. These include monitoring by independent research organisations, by consumer protection agencies and above all by a free press. Such monitoring does not just exist in principle; it has been in operation in the countries which have promoted renewable energy. In Germany, Denmark, Spain, UK, US and other countries, the media have taken an intense interest and reported in detail on costs and returns on investment in renewables. The ferocity of the debate and the contestation of the data cannot eliminate inappropriate rent seeking and political capture but we would argue that the risk can be contained. Add to this countervailing pressure from abroad. This is clearest in the case of imports of Chinese photovoltaic panels which wiped out profits of European and American manufacturers and contributed to substantial reductions in feed-intariffs. In summary, multiple forms of monitoring and countervailing pressures are critical success factors for rent management. 


\subsection{Dealing with the risk of adopting the wrong instruments}

As stressed in Sections 3 and 6, rents can be allocated in a number of ways. Different instruments work best in different circumstances, yet consultants tend to sell best practice rather than best fit. The risk of using the wrong instruments can be alleviated by testing them in selected parts of the country. China and Vietnam have become so successful in transforming their economies partly because they have a long tradition of experimenting and testing before rolling out policies country wide. India has shown, for the case of solar power, that experimenting at state level, has contributed to finding the right instruments and levels of support (Section 6). A culture of policy learning in government and in political parties further contributes to reducing the risk of adopting inappropriate instruments.

\subsection{Dealing with the risk of targeting the wrong sectors or technologies}

The risk of fostering the wrong sectors is well known in industrial policy. This is the old debate over whether governments can and should pick winners. History tells us that the most successful economies have prioritised sectors. Yes, they made mistakes in the process but making mistakes is unavoidable. It is hard to see how the green transformation can be achieved without making choices of priority sectors and technologies. In fact, choices have been made and some are controversial. For example, von Braun and Pachauri (2006) argue that fostering bio-fuels has turned out to be bad for the environment and for poor people; and Helm (2012) questions the importance given to off-shore wind power given its high cost. History will probably give a highly differentiated verdict and indicate how mistakes could have been avoided. But decisions need to be made now. Such decisions in favour of particular sectors need to include benchmarks or criteria for continuing or ending public support. As stressed by Rodrik (2007), the way forward is not to minimise the chance that a mistake might occur but to minimise the costs of mistakes when they do occur.

\subsection{Dealing with the risk of doing too little}

The most fundamental risk for the green transformation is that governments do too little and that the scaling up of investment is not achieved. Since the rent creation needed for such scaling up is politically contested we have suggested that the list of critical success factors include a supportive political coalition of actors. Section 7 stressed the need to build government-business alliances. On the one hand this is hard to achieve because public and private investors in fossil-based energy seek to protect their assets and undermine the case for renewables with any means at their disposal (Blasberg and Kohlenberg 2012). On the other hand, the formation of an alliance for renewables benefits from being able to mobilise actors with different motivations, ranging from mitigating climate change, to securing energy for the nation, building competitiveness in green sectors and generating new jobs.

Creating the political space for rent management also needs to include civil society. While the creation of rents is expected to provide considerable opportunities, in the short term it is above all the costs that are visible and need to be paid for. This requires involving civil society in building a narrative which is credible and legitimises the costs. In sum, building a government-business-civic alliance supporting the transition to renewables is essential for successful rent management, in particular for the process of creating rents and then maintaining the political space for rent allocation prioritising green objectives. Relegating the fostering of public-private-civic alliances to the sphere of 'politics' and concentrating only on technical and economic tasks is not useful if one seeks to identify the critical success factors for rent management. 


\subsection{Future research}

Having set out the terrain for future research on green industrial policy, we conclude by indicating where further digging is needed and how deeper insights can be gained. The most important step is to unpack the notion of the transformational alliance, both the transformation and the alliance bit. The green transformation is not one big project but a complex process. WGBU (2011) - drawing on the work of the historian Osterhammel depicts transformative processes as a concurrence of multiple changes which can occur at a steady or unsteady pace. Concerned with finding a way through such complexity, we would suggest focusing on actual or potential turning points and then asking who was driving the process at those turning points. In the case of China, for example, one can argue that the Renewable Energy Law of 2006 was such a turning point.

This then would provide a much needed focus for studying the role of alliances. Putting such alliances centre stage is not sufficient. We need to be able to distinguish between alliances of different types. At one end there is the strategic alliance based on joint action. At the other end there is the mere alignment of interest without co-ordination between the parties. Both can be transitional (short term) or enduring (long term). Actor constellations change over time and differ between projects and policies. Different episodes of the transformation might be supported or opposed by differently composed alliances.

The urgency of the green transformation commands that some questions are prioritised over others. One of the main questions is where the alliances come from. Are they accidental alignments of interest or are they consciously constructed and orchestrated? If the latter, who has the convening power? The state is the most likely candidate but our earlier analysis stressed that interests within the state might diverge. The key strength, but also the main difficulty, of the alliance approach lies in unpacking public, private and civic sectors and tracing alliances across these categories. If there are actors that have the convening power, one would want to find out what or who prompted them to act and how they go about forging their alliances. Such research would make a difference in that it would help us understand the political foundation for green rent management. 


\section{References}

Abdel-Latif, Abla and Schmitz, Hubert (2011) 'The Politics of Investment and Growth in Egypt: Experimenting with a New Approach', Development Policy Review 29.4: 433-58

Abdel-Latif, Abla and Schmitz, Hubert (2010) 'Growth Alliances: Insights from Egypt', Business and Politics 12.4: 1-27

Altenburg, Tilman (2011) Industrial Policy in Developing Countries: Overview and Lessons from Seven Country Cases, Discussion Paper 4/2011, Bonn: Deutsches Institut für Entwicklungspolitik/German Development Institute

Altenburg, Tilman and Engelmeier, Tobias (2012) Rent Management and Policy Learning in Green Technology Development, Discussion Paper 12/2012, Bonn: Deutsches Institut für Entwicklungspolitik/German Development Institute

Altenburg, Tilman and Pegels, Anna (2012) 'Sustainability-Oriented Innovation Systems Managing the Green Transformation', Innovation and Development 2.1: 5-22

Altenburg, Tilman; Johnson, Oliver and Schmitz, Hubert (2013) 'Rent Management Capabilities for the Green Transformation', in Anna Pegels (ed.), Green Industrial Policy in Emerging Countries, London: Routledge, forthcoming

Amsden, Alice (1989) Asia's Next Giant: South Korea and Late Industrialization, New York: Oxford University Press

Blasberg, Anita and Kohlenberg, Kerstin (2012) 'Die Klima Krieger', Die Zeit 48.22: 17-19

Bulkeley, Harriet and Newell, Peter (2010) Governing Climate Change, London and New York: Routledge

Congleton, Roger D.; Hillman, Arye L. and Konrad, Kai A. (2008) 'Forty Years of Research on Rent Seeking: An Overview', in Roger D. Congleton, Arye L. Hillman and Kai A. Konrad (eds) 40 Years of Research on Rent Seeking 2: Applications: Rent Seeking in Practice, Berlin, Heidelberg: Springer-Verlag

Evans, Peter (1995) Embedded Autonomy: States and Industrial Transformation, Princeton: Princeton University Press

FEE (2010) Energiekonzept 2050, Berlin: Forschungsverbund Erneuerbare Energien

Gerschenkron, Alexander (1962) Economic Backwardness in Historical Perspective, Cambridge, MA: Harvard University Press

Haggard, Stephan (2004) 'Institutions and Growth in East Asia', Studies in Comparative International Development 38.4: 53-81

Harrison, Tom and Kostka, Genia (2012) 'Manoeuvres for a Low Carbon State - The Local Politics of Climate Change in China and India', Research Paper 22, Developmental Leadership Program, www.dlprog.org

Heilmann, Sebastian (2008) 'From Local Experiments to National Policy: The Origins of China's Policy Process', The China Journal 59: 1-30 
Helm, Dieter (2012) The Carbon Crunch, New Haven and London: Yale University Press

Helm, Dieter (2011) 'The Sustainable Borders of the State', Oxford Review of Economic Policy 27.4: 517-35

Hepburn, Cameron (2010) 'Environmental Policy, Government, and the Market', Oxford Review of Economic Policy 26.2: 117-36

Hobday, Michael (2003) 'Innovation in Asian Industrialization: A Gerschenkronian Perspective', Oxford Development Studies 31.3: 293-314

Hongbin Cai and Triesman, Daniel (2009) 'Political Decentralization and Policy Experimentation' Quarterly Journal of Political Science 4.1:35-58

Hongbin Cai and Triesman, Daniel (2006) 'Did Government Decentralization Cause China's Economic Miracle?', World Politics 58.4: 505-35

IEA (2011) World Energy Outlook, Paris: International Energy Agency

IPCC (2007) IPCC Fourth Assessment Report: Climate Change 2007, Geneva: Intergovernmental Panel on Climate Change

Kaplinsky, Raphael (2005) Globalisation, Poverty and Inequality, Cambridge: Polity Press

Karp, Larry and Stevenson, Megan (2012) 'Green Industrial Policy: Trade and Theory', Working Paper, Department of Agricultural and Resource Economics, University of California Berkeley, http://are.berkeley.edu/ karp/GreenPolicyWB January 2012 Karp Stevenson.pdf

Khan, Mushtaq (2008) 'Governance and Development: The Perspective of GrowthEnhancing Governance', in GRIPS Development Forum (ed.), Diversity and Complementarity in Development Aid - East Asian Lessons for African Growth, Tokyo: National Graduate Institute for Policy Studies: 107-52

Khan, Mushtaq and Blankenburg, Stephanie (2009) 'The Political Economy of Industrial Policy in Asia and Latin America' in Mario Cimoli, Giovanni Dosi and Joseph E. Stiglitz (eds), Industrial Policy and Development: The Political Economy of Capabilities Accumulation, Oxford: Oxford University Press: 336-77

Krueger, Anne O. (1974) 'The Political Economy of the Rent-Seeking Society', American Economic Review 64.June: 291-303

Leftwich, Adrian (2009) 'Bringing Agency Back' in: Politics and Human Agency in Building Institutions and States. Synthesis and Overview Report of Phase One of The Leaders, Elites and Coalitions Research Programme, Research Paper 06, Department of Politics, University of York

Maxfield, Sylvia (1991) 'Bankers' Alliances and Economic Policy Patterns: Evidence from Mexico and Brazil', Comparative Political Studies 23.4: 419-58

Medema, Steven G. (1991) 'Another Look at the Problem of Rent Seeking', Journal of Economic Issues 25.4: 1049-65 
Moslener, Ulf (2012) 'Green Transformation and Global Investment: Are We On Track?', Paper presented at DIE Workshop 'Managing Economic Rents for the Green Transformation', Bonn, 6 November 2012

Newell, Peter and Paterson, Matthew (2011) 'Climate Capitalism' in Elman Altvater and Achim Brunnengräber (eds), After Cancun: Climate Governance or Climate Conflicts, Berlin: VS Verlag: 23-45

Ngo, Tak-Wing (2009) 'The Politics of Rent Production', in Tak-Win Ngo and Yongping Wu (eds), Rent Seeking in China, Abingdon and New York: Routledge

Olson, Mancur (1993) 'Dictatorship, Democracy and Development', American Political Science Review 87.3: 567-76

Peiffer, Caryn (2012) 'Reform Coalitions - Patterns and Hypotheses from a Survey of the Literature', Concept Paper 03, Developmental Leadership Program, www.dlprog.org

Rodrik, Dani (2007) 'Industrial Policy for the Twenty-first Century' in Dani Rodrik, One Economics - Many Recipes: Globalization, Institutions and Economic Growth, Princeton: Princeton University Press

Schmitz, Hubert; Dau Anh Tuan; Pham Thi Thu Hang and McCulloch, Neil (2012) Who Drives Economic Reform in Vietnam's Provinces?, IDS Research Report 76, Brighton: IDS

Schneider, Ben Ross and Maxfield, Sylvia (1997) 'Business, the State, and Economic Performance in Developing Countries', in Sylvia Maxfield and Ben Ross Schneider, Business and the State in Developing Countries, Ithaca and London: Cornell University Press

Starr, Paul (1998) 'The Meaning of Privatization', Yale Law and Policy Review 6.1: 6-41

Stern, Nicholas (2009) A Blueprint for a Safer Planet: How to Manage Climate Change and Create a New Era of Progress and Prosperity, London: The Bodley Head

Stern, Nicholas (2007) The Economics of Climate Change, Cambridge and New York: Cambridge University Press

Tollinson, Robert D. (1982), 'Rent Seeking: A Survey', Kyklos 35.4: 575-602

Tullock, Gordon (2005), The Rent Seeking Society, Indianapolis: Liberty Fund

Unruh, Gregory C. (2000) 'Understanding Carbon Lock in’, Energy Policy 28.12: 817-30

von Braun, Joachim and Pauchari, Rajendra K. (2006) The Promises and Challenges of Biofuels for the Poor in Developing Countries, Washington DC: IFPRI

von Weizsäcker, Carl Christian (2011) 'Die Große Transformation - ein Luftballon', Frankfurter Allgemeine Zeitung, 30 September 2011: 12, http://www.coll.mpg.de/download/weizsaecker/FAZ 30092011.pdf

WBGU (2011) World in Transition. A Social Contract for Sustainability, Berlin: German Advisory Council on Global Change 